\title{
The basic structural lesion of persistent neonatal hypoglycaemia with hyperinsulinism: deficiency of pancreatic $D$ cells or hyperactivity of B cells?
}

\author{
J. Rahier ${ }^{1}$, K. Fält ${ }^{3}$, H. Müntefering ${ }^{4}$, K. Becker ${ }^{4}$, W. Gepts ${ }^{2}$ and S. Falkmer ${ }^{3}$ \\ ${ }^{1}$ Department of Pathology, University Hospital St. Luc, University of Louvain in Brussels, and ${ }^{2}$ Department of Pathology, Free University \\ of Brussels, Brussels, Belgium, ${ }^{3}$ Department of Pathology, University of Lund, Malmö General Hospital, Malmö, Sweden, and ${ }^{4}$ Department \\ of Paediatric Pathology, Institute of Pathology, Johannes Gutenberg University, Mainz, FRG
}

\begin{abstract}
Summary. Pancreatic tissue obtained at subtotal pancreatectomy from 15 infants with persistent hypoglycaemia with hyperinsulinism, and autopsy specimens from 23 age-matched normoglycaemic controls, were studied with morphometric methods after immunocytochemical staining of the four main islet cell types (A, B, D and pancreatic polypeptide cells). In three cases, a focal lesion was detected by gross examination. Macroscopic or microscopic examination did not distinguish the 12 other cases from controls. As found previously, nesidioblastosis was not a specific feature of the pancreas in infantile hypoglycaemia, being observed in age-matched controls as well. In cases with hypoglycaemia the volume density of B cells was not significantly increased; that of the A cells was within normal range. The volume density of pancreatic poly-
\end{abstract}

peptide cells was markedly augmented and that of somatostatin cells was significantly decreased. The mean nuclear volume of the B cells was increased by $40 \%$ in cases with diffuse changes, but in cases with a focal lesion this increase was restricted to the abnormal area. This finding is of decisive importance for diagnosis and has therapeutic implications. The increase in B-cell nuclear size is thought to reflect an enhanced functional activity of these cells. On the other hand, the figures obtained for the volume density of B and D cells must be viewed with some reservation because degranulation may interfere with accurate detection of these cells.

Key words: Persistent hypoglycaemia, nesidioblastosis, islet cells, islet adenoma, immunocytochemistry.
Thirty years after its initial description by McQuarrie [1], the syndrome of persistent neonatal hypoglycaemia with hyperinsulinism still remains poorly understood. Nesidioblastosis [2], i.e. diffuse and disseminated proliferation of islet cells budding off from ducts, has been repeatedly proposed as the underlying pathological lesion in the pancreas [3-11]. As a consequence of this proliferation, an increase in the mass of insulin cells was proposed to be the morphological antecedent of the hyperinsulinism [12]. Recent observations based on quantitative immunohistochemical investigations have shown, however, that nesidioblastosis is a common feature of the pancreas in normal neonates and infants [13-18].

The concept of nesidioblastosis as the structural lesion underlying persistent neonatal hypoglycaemia with hyperinsulinism has thus been questioned and other aetiologies have been proposed. Thus, a decrease of somatostatin-containing cells was detected in several cases by quantitative histological/histochemical [18] and immunohistochemical [19-22] analyses of the endocrine pancreas and was corroborated by radioimmunoassay measurements of a low concentration of somatostatin in extracts of whole pancreas [20]. Other reported abnormalities are the loss of centrilobular aggregation of the endocrine cells, and the existence of small clusters of endocrine parenchymal cells throughout the exocrine tissue associated with an islet cell hyperplasia [13]. The latter lesion has been called endocrine cell dysplasia [13, 17]. Although several authors have made a distinction between cases with adenoma and those without a circumscribed lesion [24, 25], recent studies suggest that the various abnormalities observed in persistent neonatal hypoglycaemia with hyperinsulinism represent different expressions of the same basic defect $[19,23]$ and the term islet-cell dysmaturation syndrome has been proposed [26].

Despite the great number of investigations performed in this field, it remains difficult to assess which one of these manifestations could be responsible for the disease and which feature can be considered pathognomonic for histopathological diagnosis. These difficulties probably result from the small number of cases examined in each of the studies and from the limited availability of adequate controls. The aim of the present study was to determine the volume density and the rela- 
Table 1. Clinical data and laboratory findings in the patients with persistent neonatal hypoglycaemia with hyperinsulinism

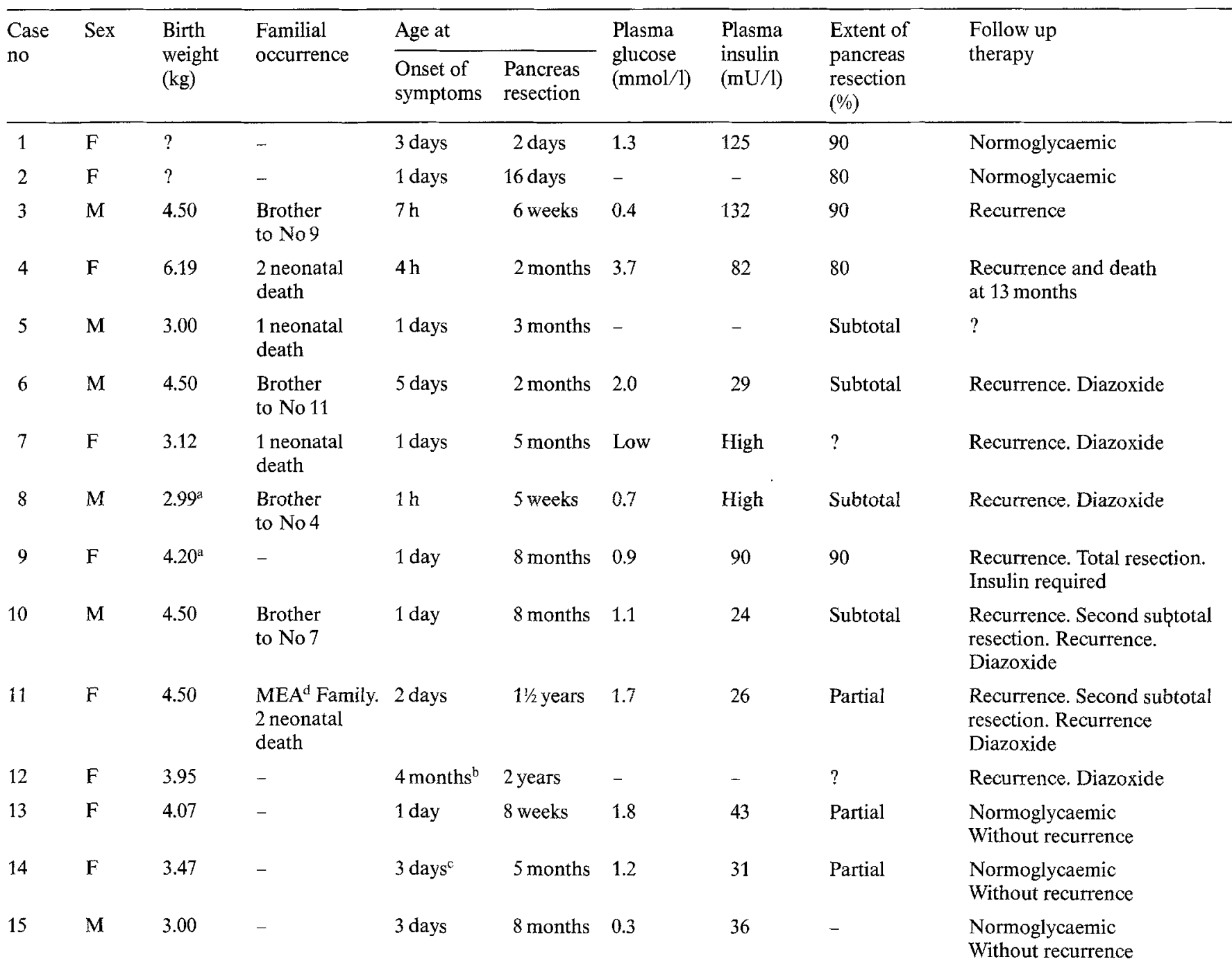

${ }^{a}$ Gestational age in case $9: 35$ weeks; in case $10: 36$ weeks; ${ }^{b}$ severe mental retardation at the age of diagnosis; ${ }^{c}$ only transient symptoms at 3 days. Severe symptoms after 3 months; ${ }^{\mathrm{d}}$ multiple endocrine adenomatosis.

tive proportions of the four principal endocrine cell types of the pancreatic islet parenchyma in a large number of cases with persistent neonatal hypoglycaemia with hyperinsulinism and in numerous age-matched control cases, using specific immunocytochemical staining techniques and precise morphometric methods.

\section{Materials and methods}

\section{Materials}

Pancreatic specimens were obtained at surgical operations (partial or subtotal pancreatectomy) from 15 infants (16 days to 2 years of age). Some clinical and laboratory data relating to these patients are given in Table 1. All children were born to non-diabetic mothers. In 13 cases, gross examination did not reveal any particular lesion in the resected pancreas (cases 1-12). In three other cases (also included in Table 1), a focal, adenomatous-like lesion was seen (cases 13-15).
For control purposes, pancreatic glands were removed within $6 \mathrm{~h}$ after death from 23 age-matched infants (seven males and 16 females), born to non-diabetic mothers. The mean birth weight was $3.1 \mathrm{~kg}$ $(2.3-3.7 \mathrm{~kg})$. Seven had died from cardiac malformation, 12 from infectious diseases and four from various diseases not known to affect the pancreas. The clinical stories of several of these cases have been reported previously, but in only one case (number 6) was the pancreas studied with immunocytochemical morphometry [22].

\section{Techniques}

Specimens from the body and the tail of the pancreatic gland were fixed in Bouin's solution and embedded in paraffin. Sections $(5 \mu \mathrm{m}$ thick) were processed by the peroxidase-antiperoxidase (PAP) technique [27]. Guinea-pig anti-insulin (Dr. P. H. Wright, Indianapolis, Indiana, USA), rabbit anti-glucagon (Dr. A.Like, Worcester, Massachusetts, USA), rabbit anti-somatostatin (Dr. W.Gepts, Brussels), and rabbit anti-bovine-pancreatic-polypeptide (PP) (Dr. R. E. Chance, Indianapolis, Indiana, USA) antisera were used at dilutions of $1 / 3,000$, $1 / 4,000,1 / 20,000$ and $1 / 40,000$, respectively, on four successive sections. Peroxidase was revealed by $3,3^{\prime}$ diaminobenzidine, and the sections were counterstained with haematoxylin. The volume density of 


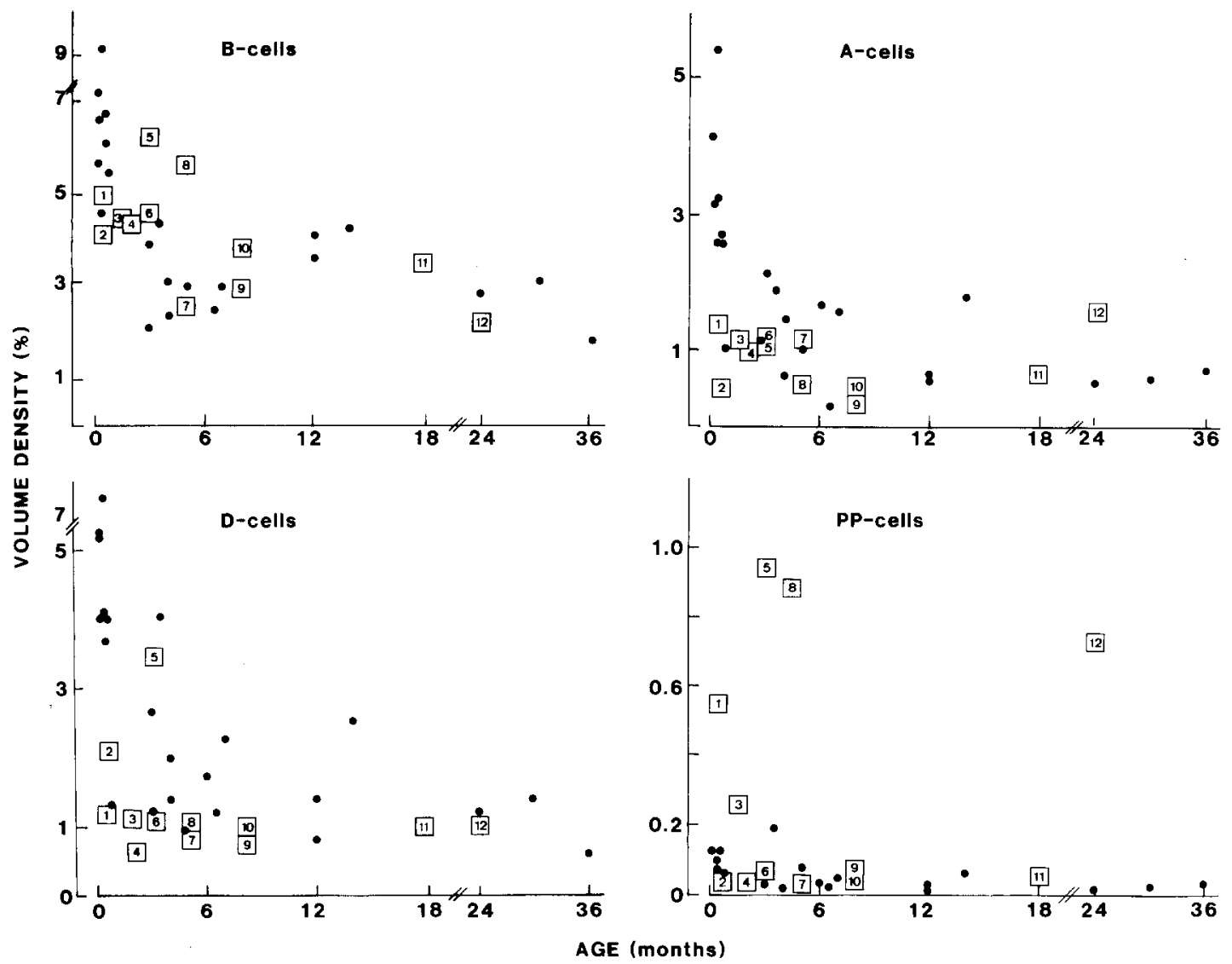

Fig. 1. Volume density of A, B, D and PP cells in control $\bullet$ and hypoglycaemic infants $\square$. (The figures in square symbols refer to case numbers in Table 1).

insulin (B), glucagon (A), somatostatin (D), and PP cells, was determined as previously described [28].

The nuclear profiles of A, B, D and exocrine cells were measured by planimetry with a semi-automatic image analyser (Videoplan, Kontron Bildanalyse, Eching, FRG) and treated by the Wicksell transformation, to obtain the actual size of the nuclei [29-31]. Nearly 800 profiles of $B$ cell nuclei were measured in each case. Nuclei of exocrine cells were also analysed, as a reference; the absence of difference between the two series excluded any effect of differences in the duration of fixation and embedding procedures. In three cases with marked hypertrophy of the B cell nuclei, the nuclei of the A and $D$ cells were also measured and compared with those from three agematched controls.

\section{Statistical analysis}

The results are expressed as mean $\pm \mathrm{SD}$. Differences were assessed with the Wilcoxon rank-sum test. The correlation between age and volume density was evaluated by the test of Spearman [32].

\section{Results}

\section{Volume density}

The volume density of each endocrine cell type is given in Figure 1. In normoglycaemic infants, the volume densities of A, B, and D cells were clearly higher at birth than after the first month of life. The decrease was rapid and significant $(p<0.01)$. The volume density of PP cells seemed to make an exception; it remained stable, at least in the body and tail of the gland. Independent of these age-related variations, the volume density of each of the four endocrine cell types was quite variable from case to case.

In hypoglycaemic infants without a focal lesion (cases 1-12), no consistent change in the volume density of the B cells was observed when compared within agematched controls. The mean value, calculated for the cases in the age group 1-36 months, was $4.03 \pm 1.28 \%$. It was only slightly higher than that in the controls $(3.23 \pm 0.85 \%)$; the differences did not reach statistical significance. For the volume density of the A cells, no differences were detected between the two groups. Although the volume density of the D cells in the pancreatic islets of the hypoglycaemic infants was often lower than that of the age-matched controls, this observation was not absolutely constant. In the age-group 1-36 months, the mean value of $\mathrm{D}$ cells volume densities $(1.17 \pm 0.81 \%)$ was significantly lower than in controls $(1.70 \pm 0.98 \% ; p<0.01)$. The volume density of the PP cells was clearly higher in five cases of persistent neonatal hypoglycaemia with hyperinsulinism; this increase was observed over the whole slice and did not result from the inclusion of a pancreatic-polypeptide-rich 
Table 2. Volume density and relative percentage of the different cell types in hypoglycaemic infants with adenomatous hyperplasia (case 13) or adenoma (cases 14,15)

\begin{tabular}{|c|c|c|c|c|}
\hline & & \multirow{2}{*}{$\begin{array}{l}\text { Within the } \\
\text { adenoma } \\
\text { Volume density }\end{array}$} & \multicolumn{2}{|c|}{ Outside the adenoma } \\
\hline & & & Volume density & $(\%)$ \\
\hline \multicolumn{5}{|l|}{ A Cells } \\
\hline & Case 13 & 0.59 & 2.28 & 26.2 \\
\hline & Case 14 & 4.96 & 2.20 & 31.6 \\
\hline & Case 15 & 4.10 & 1.24 & 27.9 \\
\hline \multicolumn{5}{|l|}{ B Cells } \\
\hline & Case 13 & 60.08 & 3.78 & 43.4 \\
\hline & Case 14 & 68.18 & 2.79 & 40.1 \\
\hline & Case 15 & 82.89 & 1.75 & 39.3 \\
\hline \multicolumn{5}{|l|}{ D Cells } \\
\hline & Case 13 & 6.48 & 2.56 & 29.4 \\
\hline & Case 14 & 1.13 & 1.94 & 27.9 \\
\hline & Case 15 & 2.00 & 1.37 & 30.8 \\
\hline \multicolumn{5}{|l|}{ PP Cells } \\
\hline & Case 13 & 2.05 & 0.08 & 0.9 \\
\hline & Case 14 & 0.17 & 0.03 & 0.4 \\
\hline & Case 15 & 11.00 & 0.09 & 2.0 \\
\hline \multicolumn{5}{|l|}{$\mathrm{B}$ to $\mathrm{A}$} \\
\hline & Case 13 & - & & 1.66 \\
\hline & Case 14 & - & & 1.27 \\
\hline & Case 15 & - & & 1.41 \\
\hline \multicolumn{5}{|l|}{$B$ to $D$} \\
\hline & Case 13 & - & & 1.48 \\
\hline & Case 14 & - & & 1.44 \\
\hline & Case 15 & - & & 1.28 \\
\hline
\end{tabular}

B TO A CELLS

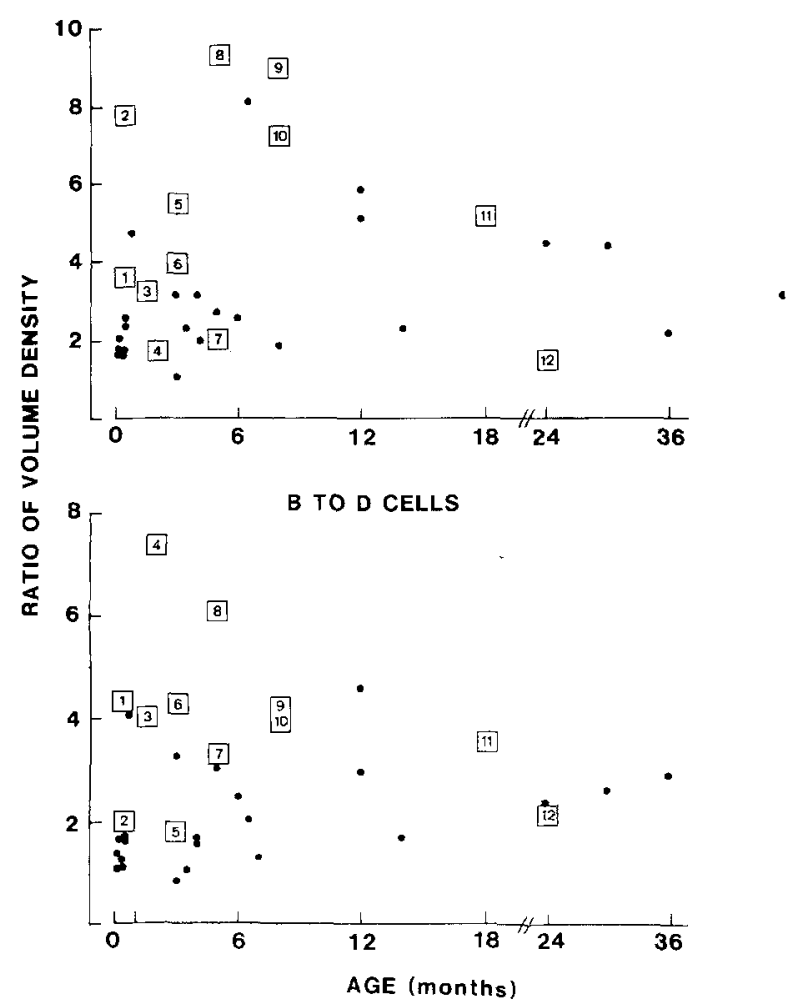

Fig. 2. Ratios of volume densities of $B$ to $A$ and $B$ to $D$ cells in control subjects and in hypoglycaemic infants $\square$. (Symbols as in Figure 1). area in the specimen. In all the other cases, the volume density of the PP cells was within the upper part of the normal range. Nevertheless, the mean for the age group 1-36 months was significantly different from that for the controls $(0.32 \%$ versus $0.04 \% ; p<0.01)$.

In the three infants with a focal lesion, one (case 13) showed a focal adenomatous hyperplasia. This lesion appeared to result from the confluence of numerous big islets, whose individual structure was essentially intact. The two others cases (14 and 15) exhibited histological features reminiscent of those usually observed in isletcell tumours of adult subjects, i. e. a compact, ribbonlike growth-pattern.

The volume density of each endocrine cell type in infants with an adenoma or an adenomatous hyperplasia is given in Table 2 . In two cases (13 and 14) the sum of the volume densities of the four endocrine cell types did not reach $100 \%$ because of the persistence of exocrine cells within and around the lesion. In the area of adenomatous hyperplasia, the volume density of B cells was similar to that found in adenomas. Outside the adenoma or adenomatous hyperplasia, the volume densities of each endocrine cell type were within the range of normal controls.

\section{Ratios of $B$ to $A$ and of $B$ to $D$ cells}

The ratios of $B$ to $A$ cells and of $B$ to $D$ cells were quite variable (Fig. 2). In normoglycaemic infants, both ratios were significantly increased with age $(p<0.01)$. In hypoglycaemic infants aged $1-36$ months without a focal lesion, the ratios of $\mathrm{B}$ to $\mathrm{A}$ cells were not significantly different from that in controls $(4.80 \pm 2.91 \%$ versus $3.40 \pm 1.88 \%$ ) but the ratios of $\mathrm{B}$ to $\mathrm{D}$ cells were significantly higher than in normoglycaemic age-matched controls $(4.05 \pm 1.65 \%$ versus $2.29 \pm 0.99 \% ; p<0.005)$. In hypoglycaemic infants both ratios tended to decrease with age. In all hypoglycaemic infants with a focal lesion, the $B$ to $A$ and $B$ to $D$ ratios outside the lesion were rather low, and similar to those observed in controls (Table 2).

\section{Relative percentages of islet cells}

The relative percentages of the four endocrine cell types are given in Figure 3. As previously reported [14], the relative proportions of $\mathrm{B}$ and $\mathrm{D}$ cells vary in opposite directions with increasing age, in normoglycaemic infants: the relative percentage of the $B$ cells increases, whereas that of the $\mathrm{D}$ cells decreases. The volume density of $B$ and $D$ cells varied from case to case but the individual differences in the relative percentages of $B$ and $D$ cells were less important than their volume density and, as a consequence, in each age group, the coefficient of variation calculated for the relative proportion of B cells and of D cells was systematically lower than that for the volume density of the same cell types.

In hypoglycaemic infants without a focal lesion, sig- 
CONTROL SUBJECTS HYPOGLYCAEMIC INFANTS

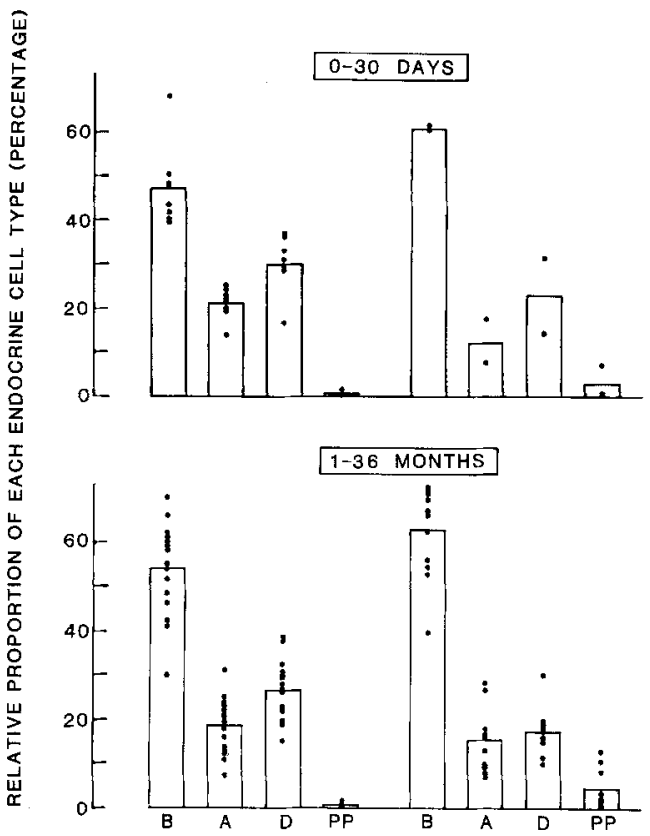

Fig.3. Percentage of each endocrine cell type, in control subjects and in hypoglycaemic infants, in the group aged 0-30 days and in the group aged 1-36 months. The values given are the means with individual variations.

nificant differences were observed in the group aged $1-36$ months, in which the relative proportion of $B$ cells was higher $(63.0 \pm 10.6$ versus $53.9 \pm 10.6 \% ; p<0.025)$ and that of $\mathrm{D}$ cells was lower $(17.2 \pm 5.1$ versus $26.6 \pm$ $7.1 \% ; p<0.001)$ than in age-matched controls.

In hypoglycaemic infants with a focal lesion, the relative proportion of $\mathrm{B}$ cells in the lesion was similar in cases with adenoma and in that with adenomatous hyperplasia. It averaged $87 \%$. The proportion of the different types of non-B cells was quite variable from case to case (Table 2). Outside the lesion, the proportion of each cell type remained in the range of normal subjects. The proportion of D cells was nearby $29 \%$ and equal to control values in each of these cases.

\section{Nuclear size of the islet cells}

In normoglycaemic infants, hypertrophic nuclei were never observed, neither in the B cells, nor in A, D or exocrine cell types (Fig. 4). A histogram of the distribution of the radius of the B cell nuclei is shown in Figure 5. The distribution was approximately Gaussian; a comparison between individual values did not disclose any differences.

In hypoglycaemic infants without a focal lesion, a characteristic histopathological feature was observed, i. e. the presence of giant B cell nuclei (Fig. 4). As illustrated for case 9 (Fig. 5), the histogram of the distribution of the radii of the B cell nuclei was markedly different from that for the age-matched controls. The distribution curve was not only shifted towards higher sizes, but also disclosed the presence of different populations of $\mathrm{B}$ cell nuclei, which is consistent with the giant nuclei observed in some of the B cells (Fig.4). This particular feature, although present in each case, became less obvious when the data were pooled because of individual variations. The mean nuclear radius of the $B$ cells $(2.99 \pm 0.38 \mu \mathrm{m})$ was significantly larger than that in the controls $(2.68 \pm 0.23 \mu \mathrm{m} ; p<0.001)$. In contrast, the radius of the nucleus of the A cells and of that of the nuclei of the exocrine cells was not different in control and hypoglycaemic subjects. Rarely, D cells with a large nucleus were observed.

In hypoglycaemic infants with an adenoma or an adenomatous hyperplasia, a distinction was made between the $B$ cell nuclei within and those outside the lesion (Fig. 5). In the adenoma or the adenomatous
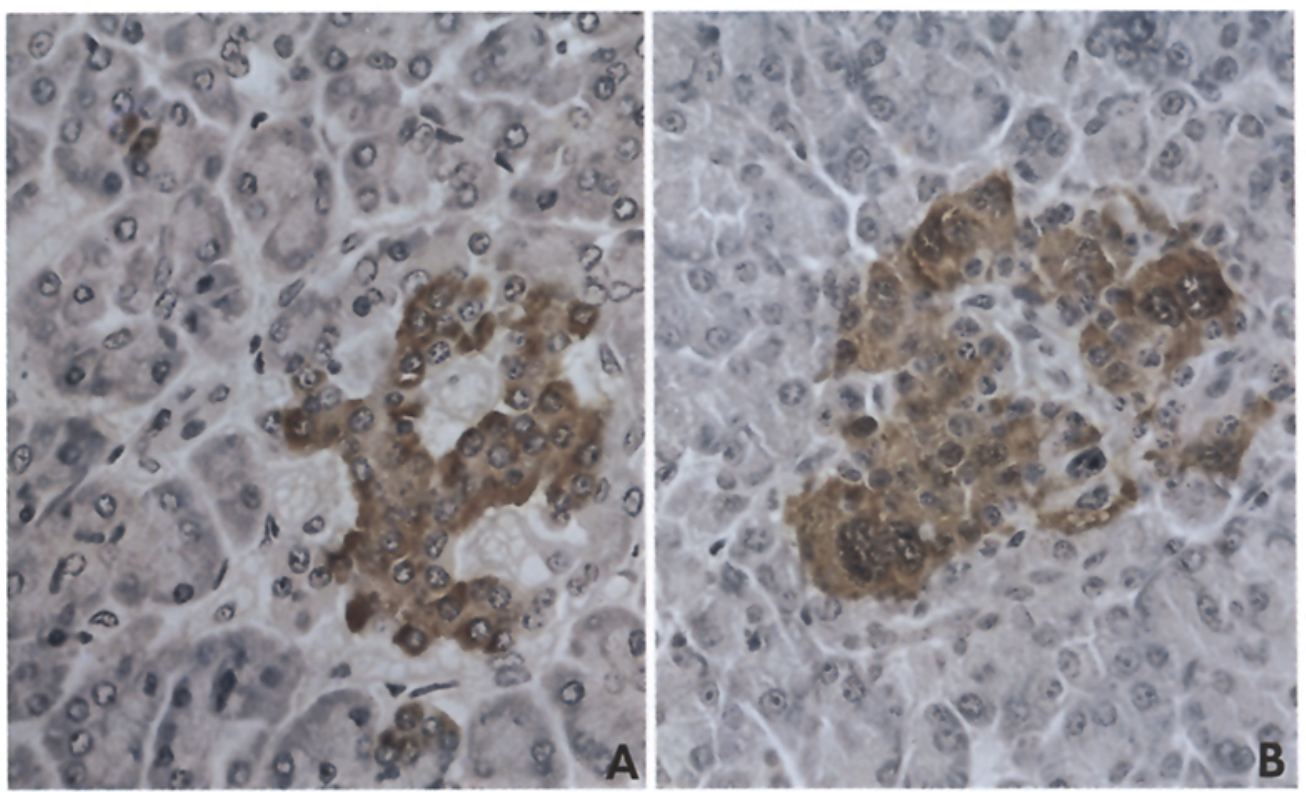

Fig. 4A and B. Pancreatic tissue processed by the peroxidase-antiperoxidase technique with anti-insulin serum and counterstained with haematoxylin. A Control subject. The B cell nuclei are small and regular in size and shape. B Hypoglycaemic infant. Numerous B cell nuclei are distinctly larger and more prominent than normally 

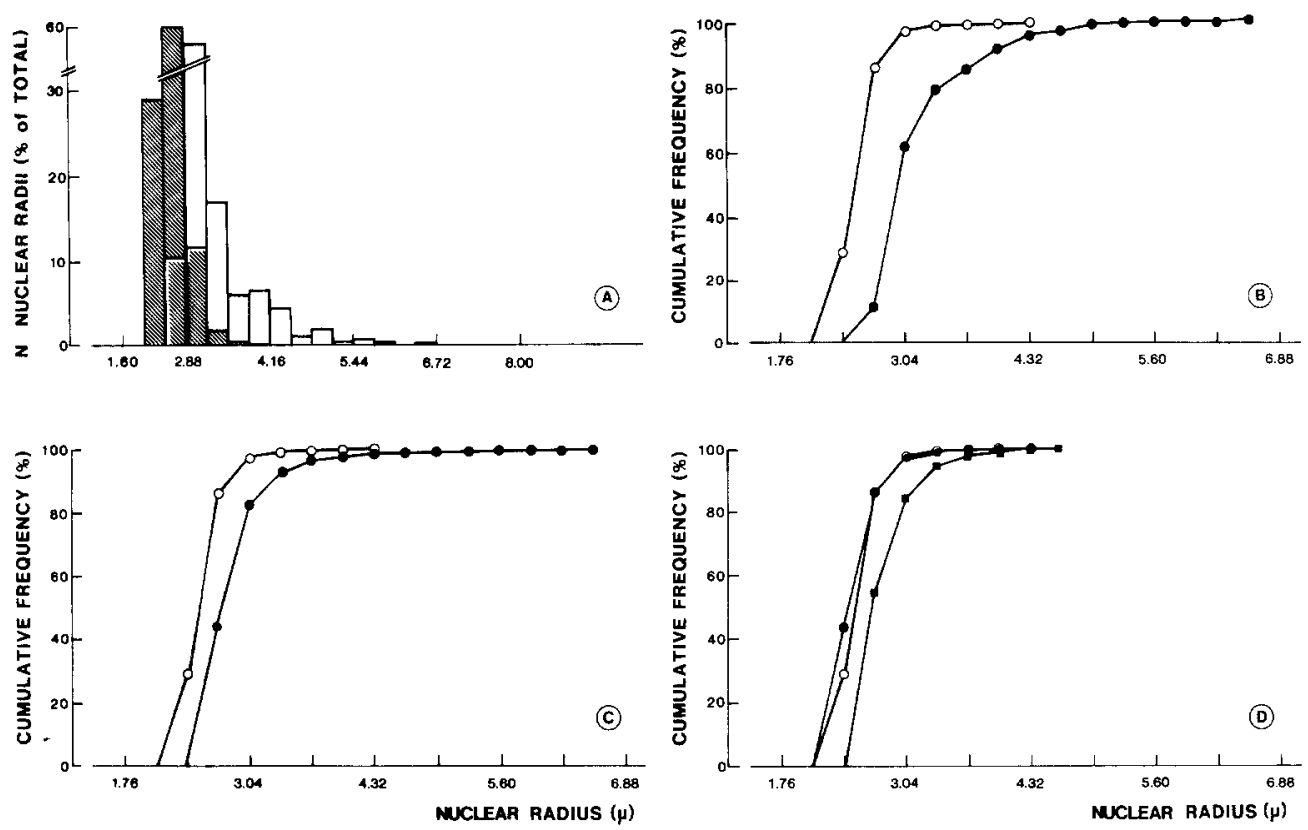

Fig.5. A Histogram of B-cell nuclear radii in control subjects ( $\mathbb{Q}$ ) and in case 9 with persistent hypoglycaemia ( $\square$ ). B and C Cumulative frequency curve of B-cell nuclear radii in control subjects $(O)$ and in case 9 with persistent hypoglycaemia $(\mathbf{B})$ or in all cases with hypoglycaemia $(\mathbf{C})$. D Cumulative frequency curve of B-cell nuclear radii in adenomas ( $\mathbf{U})$ and outside adenomas $(\mathbf{)})$. Controls are shown by (O)

hyperplasia, the mean $B$ cell radius was increased $(2.95 \pm 0.32 \mu \mathrm{m})$. Consequently the cumulative frequency curve was slightly shifted to the right. In contrast, the radius of the B-cell nuclei measured in cells outside the adenoma was equal to - or even slightly smaller than that of the B cells of the control cases. Thus, the cumulative frequency curve was slightly shifted to the left.

The frequency of $B$ cell nuclei with a radius higher than twice the mean of that of normal B cell nuclei was $0.02 \%$ in controls, $0.11 \%$ outside the focal lesion, $0.74 \%$ in the focal lesion and $1.46 \%$ in cases with persistent neonatal hypoglycaemia with hyperinsulinism without focal lesion.

\section{Discussion}

As explained in the Introduction, nesidioblastosis as originally defined can no longer be considered a pathognomonic feature of persistent neonatal hypoglycaemia with hyperinsulinism. If excessive nesidioblastosis had indeed been the factor responsible for persistent neonatal hypoglycaemia with hyperinsulinism, one would have expected a large excess of B cells after 6 months of duration. The results of our study, based on a large group of infants, as well as those of others $[13,17]$, clearly demonstrate that the volume density of the B cells is at the very most only slightly higher in the pancreas of cases with persistent neonatal hypoglycaemia with hyperinsulinism than in age-matched controls. An increase in size of the B cell nuclei may well have contributed to the apparent increase in volume density on the one hand, but on the other hand a degranulation of hyperactive B cells may have interfered with their detection and therefore erroneously decreased their volume density. As the pancreas is never completely resected at operation, the total mass of $\mathrm{B}$ cells cannot be calculated from the volume density. However, there is no evidence that the pancreas is increased in size in these hypoglycaemic infants. On the other hand, several lines of evidence suggest that the primary cause of the disease is not an increase in the B cell mass; the absence of an increase in some cases with proven hyperinsulinism indicates that this occasional increase may be coincidental. Moreover, if hyperinsulinism were indeed due to B cell hyperplasia, it would be difficult to explain why the condition is not always cured after a $80 \%$ resection of the pancreas, as observed in our series and in those of others [11, 33, 34]. In contrast, cases with adenoma or focal adenomatous hyperplasia can be restored to normoglycaemia by a partial resection only. All these facts suggest that the initial basic lesions relate to the function of the B cells rather than to their number. This concept is consistent with a study in vitro of the insulin released by islets isolated from a pancreas of a case with persistent neonatal hypoglycaemia with hyperinsulinism, in which an abnormal sensitivity of B cells to glucose was demonstrated [35].

Since somatostatin has been shown to inhibit insulin secretion, a quantitative deficiency of $\mathrm{D}$ cells has also been incriminated in the aetiology of persistent neonatal hypoglycaemia with hyperinsulinism. As also stated in the Introduction, several recent studies of persistent neonatal hypoglycaemia with hyperinsulinism [13, 19-22] have shown that the volume density of D cells 
was lower than in controls. The results of the present study confirm that when strictly age-matched controls are used, a decrease in volume density of $D$ cells can, indeed, be established. However, a decrease in the volume density of D cells is not uniformly present in all cases of persistent neonatal hypoglycaemia with hyperinsulinism. Moreover, the reduced volume density of $\mathrm{D}$ cells in the cases with hypoglycaemia must be interpreted with some caution; degranulation of the cells might impair their detection and thus lead to an underestimation of the actual number of $D$ cells. The observation of weakly stained D cells and the description by means of electron microscopy of poorly granulated D cells [11; J. Rahier, unpublished observations] are both in agreement with this interpretation. Measurements of peripheral plasma levels of somatostatin in infants with persistent neonatal hypoglycaemia with hyperinsulinism might eventually help to understand the role of this hormone in the disease, but it remains to be demonstrated that peripheral levels are an adequate reflection of local concentrations of this hormone with its rapid degradation and essentially paracrine mode of function.

Contrary to the volume density of A cells which does not change in cases with persistent neonatal hypoglycaemia with hyperinsulinism, that of pancreatic polypeptide cells was increased. Although in healthy subjects, hypoglycaemia has been reported to increase the plasma levels of pancreatic polypeptide [36], it is improbable that repeated hypoglycaemia in these infants is responsible for the observed hyperplasia of this cell type, since it is not present in cases with focal lesions. However, the biological significance of changes affecting cells that are so rare, remains unclear.

The occurrence of polyploid B cells in adult human endocrine pancreas has previously been well documented [37] and the presence of giant B cell nuclei in the pancreas of cases with persistent neonatal hypoglycaemia with hyperinsulinism have been reported $[3,13,18$, 38-40]. The present study is, however, the first quantitative analysis of these phenomena in the islet parenchyma in cases with persistent neonatal hypoglycaemia with hyperinsulinism and in the age-matched normoglycaemic infants. The increase in nuclear volume of the B cells was observed in all cases of persistent neonatal hypoglycaemia with hyperinsulinism without a focal lesion. This observation could thus be of diagnostic importance. When observed in the pancreas in a case of persistent neonatal hypoglycaemia with hyperinsulinism, it indicates that the lesion involves the whole pancreas, and that an adenoma or an adenomatous hyperplasia can be ruled out as a cause of the disease. When the nuclei are of normal size, a focal lesion should be suspected and looked for by all possible means.

The exact significance of the hypertrophy of the B cell nuclei remains somewhat unclear. The size of a nucleus has classically been thought to reflect the cell function [41]. This method of evaluating functional activity has been commonly used for endocrine cells in many experimental conditions, both in vitro [42] and in vivo [43]. Polyploidy is an alternative cause of nuclear enlargement and is often also correlated with an increase in a secretory function [44]. It is thus plausible that both the increase in B cell nuclear size and the polyploidy of some of the B cells reflect a hyperfunction. Whether these nuclear features represent a primary abnormality of the B cells as the cause of persistent neonatal hypoglycaemia with hyperinsulinism, or whether they are secondary to a loss - or an impairment - of the mechanisms controlling $\mathrm{B}$ cell function, remains to be established. In this respect a derangement of the structural organization of the islets with a failure to develop normal intercellular communications between islet cells is an attractive hypothesis, requiring further investigations.

It has been proposed that the spectrum of morphological alterations reported in persistent neonatal hypoglycaemia with hyperinsulinism, i.e. nesidioblastosis, islet hypertrophy and islet cell hyperplasia, focal hyperplastic adenomatosis, and adenoma, could be the expression of one and the same basic defect [26]. This might be true from a theoretical point of view. But, the fact that in persistent neonatal hypoglycaemia with hyperinsulinism cases with the focal adenoma-like lesion the B-cell nuclei outside the adenoma have an ultrastructure indicative of reduced functional activity [45], the existence of a normal volume density of $B$ and $D$ cells and a rather low ratio of $B$ to $D$ cells outside the adenoma, as well as the clinical observation that such cases are cured by a partial pancreatectomy, all constitute arguments for clinicians and pathologists to discriminate between these two different aspects of persistent neonatal hypoglycaemia with hyperinsulinism.

Acknowledgements. This work was supported by grants 3.4560 .81 (JR) from the Fonds de la Recherche Scientifique et Médicale, Brussels and 3.0024.82 (WG) from the Fonds Wetenschappelijk Geneeskundig Onderzoek, Brussels. It was also supported by grants from the Swedish Medical Research Council (Project No 12X-718), the Swedish Diabetes Association, the Cancer Research Foundation of Malmö General Hospital and the Faculty of Medicine, University of Lund, Sweden. We also gratefully acknowledge the kind help from our colleagues who provided us with clinical data for the patients and those for the controls, Dr. J.C. Henquin for advice and critical reading of the manuscript, Miss A. Lefevre, Mrs. S. Vandeputte-Loozen and Mrs. R.-M.Janssen-Goebbels for technical assistance. Lastly, we thank Drs. R.E.Chance, A.Like and P.H. Wright for generous supply of antisera. A preliminary report was given at the XIth International Diabetes Federation Congress in Nairobi, 10-17 November 1982, and at the Meeting of the Swedish Association of Pathologists, held in Karlskrona/Ronneby, 15-16 April 1983.

\section{References}

1. McQuarrie I (1954) Idiopathic spontaneously occuring hypoglycemia in infants. Clinical significance of problem and treatment. Am J Dis Child 87: 399-428

2. Laidlaw GF (1938) Nesidioblastoma, the islet tumor of the pancreas. Am J Pathol 14: 125-134

3. Brown RE, Young RB (1970) A possible role for the exocrine pan- 
creas in the pathogenesis of neonatal leucine-sensitive hypoglycemia. Am J Dig Dis 15:65-72

4. Yakovac WC, Baker L, Hummeler K (1971) Beta cell nesidioblastosis in idiopathic hypoglycemia of infancy. I Pediatr 79:226-231

5. Grampa G, Gargantini L, Grigolato PG, Chiumello G (1974) Hypoglycemia in infancy caused by beta cell nesidioblastosis. Am J Dis Child 128: 226-231

6. Woo D, Scopes JW, Polak JM (1976) Idiopathic hypoglycemia in sibs with morphological evidence of nesidioblastosis of the pancreas. Arch Dis Child 51: 528-531

7. Thomas CG, Underwood LE, Carney CN, Dolcourt JL, Whitt JJ (1977) Neonatal and infantile hypoglycemia due to insulin excess: New aspects of diagnosis and surgical management. Ann Surg 185: $505-517$

8. Heitz PU, Klöppel G, Häcki WH, Polak JM, Pearse AGE (1977) Nesidioblastosis; the pathologic basis of persistent hyperinsulinemic hypoglycemia in infants: morphologic and quantitative analysis of seven cases based on specific immunostaining and electron microscopy. Diabetes 26: 632-642

9. Becker K, Wendel U, Przyrembel $H$, Tsotsalas $M$, Müntefering $H$, Bremer HJ (1978) Beta cell nesidioblastosis. Eur J Pediatr 127 : $75-89$

10. Dahms BB, Landing BH, Blaskovics M, Roe TF (1980) Nesidioblastosis and other islet cell abnormalities in hyperinsulinemic hypoglycemia of childhood. Hum Pathol 11: 641-649

11. Aynsley-Green A (1981) Nesidioblastosis of the pancreas in infancy. In: Randle PJ, Steiner DF, Whelan WJ (eds). Carbohydrate metabolism and its disorders. Academic Press, London. pp 181-204

12. Liechty RD, Alsever RN, Burrington J (1974) Islet cell hyperinsulinism in adults and children. JAMA 230: 1538-1543

13. Jaffe R, Hashida Y, Yunis EJ (1980) Pancreatic pathology in hyperinsulinemic hypoglycemia of infancy. Lab Invest 42: 356-365

14. Rahier J, Wallon J, Henquin JC (1981) Cell populations in the endocrine pancreas of human neonates and infants. Diabetologia 20: $540-546$

15. Gould VE, Memoli VA, Dardi LE, Gould NS (1981) Nesidiodysplasia and nesidioblastosis of infancy. Scand $J$ Gastroent 16: 129-142

16. Karnauchow PN (1982) Nesidioblastosis in adults without insular hyperfunction. Am J Clin Pathol 78: 511-513

17. Gould VE, Memoli VA, Dardi LE, Gould NS (1983) Nesidiodysplasia and nesidioblastosis of infancy: structural and functional correlations with the syndrome of hyperinsulinemic hypoglycemia. Pediatr Pathol 1: 7-31

18. Sovik O, Viđnes J, Falkmer S (1975) Persistent neonatal hypoglycemia. Acta Pathol Microbiol Scand [A] 83: 155-166

19. Heitz PU, Klöppel G, Polak JM (1980) Morphology of the endocrine pancreas in persistent hypoglycaemia in infants. In: Andreani D, Lefevre PJ, Marks V (eds). Current views on hypoglycaemia and glucagon. Proceedings of the Serono Symposia, 1979, vol 30. Academic Press, London, pp 355-365

20. Bishop AE, Polak JM, Chesa PG, Timson CM, Bryant MG, Bloom SR (1981) Decrease of pancreatic somatostatin in neonatal nesidioblastosis. Diabetes 30: 122-126

21. Falkmer S, Sovik O, Vidnes J (1981) Immunohistochemical, morphometric, and clinical studies of the pancreatic islets in infants with persistent neonatal hypoglycemia of familial type with hyperinsulinism and nesidioblastosis. Acta Biol Med Germ 40:39-54

22. Falkmer $S$, Rahier J, Sovik O, Vidnes J (1981) Significance of argyrophil parenchymal cells in the pancreatic islets in persistent neonatal hypoglycemia with hyperinsulinism of familial type. Upsala J Med Sci 86: 111-117

23. Shermeta DW, Mendelsohn G, Haller JA (1980) Hyperinsulinemic hypoglycemia of the neonate associated with persistent fetal histology and function of the pancreas. Ann Surg 191: 182-186

24. Schwartz JF, Zwiren GT (1971) Islet cell adenomatosis and adenoma in an infant. J Pediatr $79: 232-238$
25. Fonkalsrud EW, Trout HH, Lippe B, La Franchi S, Dakake C (1974). Idiopathic hypoglycemia in infancy. Arch Surg 108: 801-804

26. Gabbay KH (1978) Case records of the Massachusetts General Hospital. New Engl I Med 299: 241-248

27. Sternberger LA (1979) Immunocytochemistry. John Wiley \& Sons. New York, $p 104$

28. Rahier J, Goebbels RM, Henquin JC (1983). Cellular composition of the human diabetic pancreas. Diabetologia $24: 366-371$

29. Wicksell SD (1925) The corpuscule problem. A mathematical study of a biometric problem. Biometrika 17:84-89

30. Wicksell SD (1926) The corpuscule problem. Second memoire. Case of ellipsoidal corpuscules. Biometrika 18:151-172

31. Baudhuin P (1968) L'analyse morphométrique quantitative des fractions subcellulaires. Thésis. Université Catholique de Louvain

32. Snedecor GW, Cochran WG (1967) Statistical methods, 6th edn. The Iowa State University Press. Ames, Iowa, USA

33. Moazam F, Rodgers BM, Talbert JL, Rosenbloom AL (1982) Near-total pancreatectomy in persistent infantile hypoglycemia. Arch Surg 117: 1151-1154

34. Kramer JL, Bell MJ, De Schryver K, Bower RJ, Ternberg JL, White NH (1982) Clinical and histologic indications for extensive pancreatic resection in nesidioblastosis. Am J Surg 143: 116-119

35. Aynsley-Green A, Polak JM, Bloom SR, Gough MH, Keeling J, Ashcroft SJH, Turner RC, Baum JD (1981) Nesidioblastosis of the pancreas: definition of the syndrome and the management of the severe neonatal hyperinsulinaemic hypoglycaemia. Arch Dis Child 56: 496-508

36. Floyd JC, Fajans SS, Pek S (1976) Regulation in healthy subjects of the secretion of human pancreatic polypeptide, a newly recognised pancreatic islet polypeptide. Trans Assoc Am Physicians 89: 146-158

37. Ehrie MG, Swartz FJ (1974) Diploid, tetraploid and octaploid beta cells in the islets of Langerhans of the normal human pancreas. Diabetes 23: 583-588

38. Haddad HM, Roberts WC, Pronove P, Bartter FC (1962) Leucineinduced hypoglycemia. New Engl J Med 267: 1057-1060

39. Misugi K, Misugi N, Sotos J, Smith B (1970) The pancreatic islet of infants with severe hypoglycemia. Arch Pathol $89: 208-220$

40. Klöppel G, Altenähr E, Reichel W, Willig R, Freytag G (1974) Morphometric and ultrastructural studies in an infant with leucine-sensitive hypoglycemia, hyperinsulinism and islet hyperplasia. Diabetologia 10:245-252

41. Kracht J (1958) Morphologische Kriterien zur Beurteilung der Inselaktivität. Endokrinologie 36: 146-158

42. Bowen RE, Swartz FJ (1976) The ultrastructure of polyploid B-cells in the islets of normal mice. Diabetologia 12: 171-180

43. Hellman B, Hellerström C (1959) Size differences of the B-cell nuclei in the islet tissue of normal and alloxan-treated rats. Acta Pathol Microbiol Scand 45: 113-122

44. Wagner D, Richart $R$ (1968) Polyploidy in the human endometrium with the Arias-Stella reaction. Arch Pathol 85: 475-480

45. Klöppel G, Altenähr E, Menke B (1975) The ultrastructure of focal islet cell adenomatosis in the newborn with hypoglycemia and hyperinsulinism; contribution to the classification of neonatal insulinomas. Virchows Arch [Path Anat] 366: 223-236

Received: 20 June 1983

and in revised form: 28 November 1983

\section{Dr. J. Rahier}

Department of Pathology

University Hospital St Luc

Avenue Hippocrate 10

B-1200 Brussels

Belgium 